\title{
岐阜駅前繊維問屋街における街区建設の経緯に関する研究 STUDY ON THE CITY BLOCK CONSTRUCTION OF THE TEXTILE WHOLESALE DISTRICTS IN THE GIFU RAILWAY STATION-FRONT AREA.
}

\author{
荒木 菜見子 ${ }^{* 1}$, 中川 理 ${ }^{* 2}$ \\ Namiko ARAKI and Osamu NAKAGAWA
}

\begin{abstract}
This study targets the textile wholesale districts in front of JR Gifu railway station, and prospects the period from the post-war to the disaster prevention construction zone project. We tried to clarify the process of the city block formation and its transformation. In the nationwide fireproofing movement, city blocks formed by wooden shops were redeveloped to reinforced concrete buildings in front of Gifu railway station. Following up on some examples of these, it became clear that there were changes in the business form and significance of the cooperation of blocks in about 20 years.
\end{abstract}

\author{
Keywords : Gifu City, Station front, Commercial area, Textile wholesale district, Disaster Prevention Building Block Development, Communal building \\ 岐阜市, 駅前, 商業地区, 繊維問屋街, 防災建築街区, 共同建築
}

\section{1.はじめに}

わが国の終戦直後の混乱期には、駅前等に多くの市場が形成され た。最初に現れたのは、物価統制にはずれた非合法な「闇市」を中 核とするものであり、その形成過程についての研究が進められてい る注1)。また、その後の 1950 年代から進んだ都市不燃化運動や、そ の成果として 1952(昭和 27)年に施行された耐火建築促進法、後継 の防災建築街区造成法による商業店舗の防火建築帯化の事業につい ての研究も進められつつある注2)

これらの研究は、戦後における小売業を中心とした商業地区の発 生と、その後の地区形成・建設の観点から分析されたものである。 しかし、一方で戦後の都市空間における街区形成については、一つ の産業を基盤とすることで市街地形成が進んだ地域もあった。そこ では、特定の産業の興隆にともない、闇市」と同様の自律的な街区 創出から、共同化された不燃化事業へと繋がる動きが、関連しなが ら連続して見られることが期待できるだろう。

戦後における日本の産業基盤を作り上げたものの一つとして繊維 産業が挙げられる。そして、実際に多くの地方都市において、繊維 産業を中核とした街の発展が実現している。そこで、本稿ではその 典型として考えられる岐阜市を取り上げる。岐阜においては、戦後 直後に駅前に木造バラックが建設し古着の売買を行う、ハルピン街 という商店街が建設された。さらにその後、大ハルピン街と呼ばれ る住宅街の建設も行われている。われわれはすでにその実態を明ら かにしたが注3)、その後、このハルピン街・大ハルピン街の出身者ら と、市内在住の繊維業者らが中心となって 1950(昭和 25)年頃から
岐阜駅前において繊維問屋街の建設が進められていくことになる。 本稿では、この繊維問屋街の建設に注目する。そこでは、その前身 として位置付けられる自律的な商店街、ハルピン街・大ハルピン街 を引き継ぎながら、都市不燃化を目指寸制度の下で、事業の共同化 が進められ街区が建設されていった過程を見ることができる。その 過程の分析は、わが国戦後の市街地形成の実相を明らかにする上で 重要なものとなると判断できるだろう。

その経緯について明らかにする資料としては、新聞記事や、公的 資料、とりわけ防災建築街区造成事業に関わる行政文書・図面類な どを見出すことができる。しかし、それらはあくまで個別の事業に 関わる資料である。もちろん、本稿はそれらの事業の詳細を明らか にすることを主な目的とするが、その上で注目したのは、それぞれ の事業での商店主たちの主体的な共同化の動きであり、それが制度 による支援や制約を受けながら、どのように発動し街区を建設する ことになったのかについてである。そのことを明らかにするために は、事業相互の関係を整理する必要がある。それについては、さい わいに岐阜既製服産業連合会がまとめた『岐阜既製服産業発展史』 注 4 ) 、岐阜繊維問屋町連合会の結成 20 周年に出版された『問屋町 の歩み』注5)に、網羅したものではないが概略を示寸記録がある。そ こで本稿では、これらの資料 (以後『岐阜既製服産業発展史』は「発 展史」と記載）を手がかりとしながら、そうした資料では記述され ていない、事業の具体的な建設経緯と空間構成について、建築史、 あるいは都市計画史の観点からの検証を行う。
*1 京都工芸瀻維大学大学院建築学専攻 大学院生·工修

*2 京都工芸繊維大学デザイン・建築学系 教授・工博
Grad. Student, Dept. of Architecture, Kyoto Institute of Technology, M.Eng. Prof., Faculty of Design and Architecture, Kyoto Institute of Technology, Dr.Eng. 


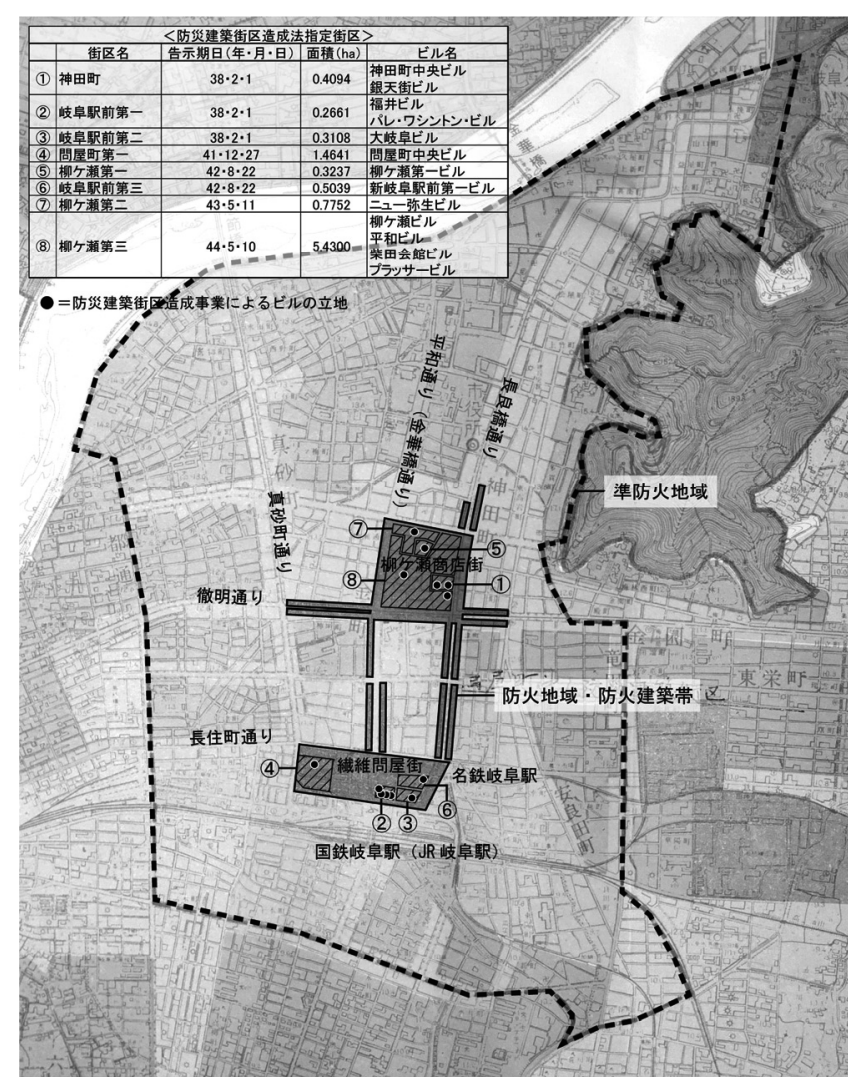

Fig. 1 Arrangement of the designated blocks for quasi-fire prevention zones, the fire prevention zones, the fire prevention building zones, and the Disaster Prevention Building Blocks.

図 1 準防火地域、防火地域、防火建築帯、防災建築街区造成法の 指定街区の配置注 ${ }^{14)}$

\section{2. 岐阜市における都市不燃化の動き}

前述のとおり、戦後直後の岐阜駅前において、北満州からの引揚 者集団が一人のリーダーの強いリーダーシップの下に、木造バラッ クで古着の売買を行う、ハルピン街という商店街を建設した注6)。こ れは、行政の支援や規制を受けないという意味で、闇市」と同様に 自律的な商業地の形成として捉えられるものであった。しかし、そ の後 1950 年代より全国に広がった耐火建築により都市不燃化を目 指寸運動の進行により、そのための制度も作られていく。それを受 け岐阜においても、その制度の下に新たな問屋街が建設されていく 展開が見られた。そこで、まず街区建設の前提となった不燃化を目 指す事業や制度が、岐阜においてどのように展開されたのかを確認 する。

\section{2-1. 耐火建築促進法と防災建築街区造成法による地域指定}

1950 年代以降の耐火建築による都市建設を目指した都市不燃化 運動が広がる中で、岐阜駅前においても、そうした運動に連動する 事業が展開されることになる。その中で、まず確認しておかなけれ ばならないのは、耐火建築促進法・防災建築街区造成法とそれに関 連する制度の適応である。

耐火建築促進法は、不燃化運動を制度的に支えるために 1952(昭 和 27)年 5 月に公布されたものである。これにより国庫及び地方公 共団体による助成を受けて耐火建築の建設促進が図られることとな り、多くの都市で、防火建築帯の造成が行われることになった。岐 阜市においては 1952(昭和 27) 年 9 月に市議会全員協議会で防火建
Table 1 Timeline of district construction and fireproofing movement. 表 1 繊維問屋街建設と都市不燃化に関わる年表

\begin{tabular}{|c|c|c|c|}
\hline & & ＜問屋街·建物の建設＞ & <制度・組織 > \\
\hline 1950 年 & & マルフジ織維街建設 & \\
\hline 1951 年 & & $\begin{array}{l}\text { 問屋町中央通り建設 } \\
\text { 問屋町一条通り建設 } \\
\text { 現金問屋街建設 }\end{array}$ & \\
\hline 1952 年 & & & 耐火建築促進法公布 \\
\hline 1953 年 & & & 防火建築带の指定 \\
\hline 1954 年 & & $\begin{array}{l}\text { 中問屋町建設(第一期工事は問屋町の中では初めて } \\
\text { のRC造) }\end{array}$ & \\
\hline 1959 年 & 6月 & マルフジ第ービル第一期工事が完了 & $\begin{array}{l}\text { 1月 } \quad \text { 岐阜不燃都市建設協議会結成 } \\
11 \text { 月 } \\
\text { 岐阜問屋町耐火建築促進会結成 }\end{array}$ \\
\hline 1961 年 & $\begin{array}{l}\text { 8月 } \\
\text { 9月 }\end{array}$ & $\begin{array}{l}\text { 現金問屋街の再開発計画についての新聞報道あり。 } \\
\text { 成屋町一通ビル竣工(不燃化ビル建設計画第一号) }\end{array}$ & 6月 防災建築街区造成法制定 \\
\hline 1963 年 & 3月 & $\begin{array}{l}\text { マルフジ第ービルの桩大エ事が完了 } \\
\text { 福井ビル建設(岐阜駅前第一街区) }\end{array}$ & \\
\hline 1965 年 & 11月 & マルフジ織維街三条通付近から出火 & \\
\hline 1966 年 & & $\begin{array}{l}\text { マルフジ第ービル改築(ビルの一部をRC3階建の防火 } \\
\text { 建築に改築) }\end{array}$ & 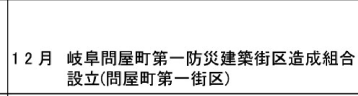 \\
\hline 1967 年 & 11月 & $\begin{array}{l}\text { 間屋町中央通以、現金問屋街の不燃化ビル完成(問屋 } \\
\text { 第一街区) }\end{array}$ & \\
\hline 1968 年 & & & $\begin{array}{ll}6 \text { 月 } & \begin{array}{l}\text { 岐阜駅前瀻維防災建築街区造成組合設 } \\
\text { 立岐卓駅前第一街区) }\end{array}\end{array}$ \\
\hline 1971 年 & 9月 & $\begin{array}{l}\text { まるふじ商事(株)が 12階建てピルの建設、大型スー } \\
\text { パー誘致計画を発表 頓挫。 }\end{array}$ & \\
\hline 1973 年 & 4月 & $\begin{array}{l}\text { パレワシントンビルの建設開始(岐阜駅前第一街区) } \\
\text { 全馆完成は1974年 }\end{array}$ & \\
\hline
\end{tabular}

築帯についての計画案が示され、1953(昭和 28 )年 2 月 12 日建設省 告示第 149 号で防火建築帯が指定され、当年度から耐火建築の助成 に努めるようになった注7)。

耐火促進法を引き継ぐ形で、1961(昭和 36)年に防災建築街区造成 法が制定された。耐火建築促進法では道路両側沿いの各 $11 \mathrm{~m}$ 幅の範 囲をその対象とし、線的な防火対策に留まるものであったのに対し、 防災建築街区造成法では街区ごとの指定が可能となり、より面的な 防火対策が可能となった。また、防災建築街区に指定された街区で はそれぞれ防災建築街区造成組合を結成し事業推進母体とすること とされた注8)。岐阜市における最初の街区指定は 1963(昭和 38)年に 行われ、1974(昭和 49)年までに敷地面積延 17,591 $\mathrm{m}^{2}$ の木造建物が 除去され、そこに 13 軒の 3 から 12 階建ての中高層ビルが建てられ た(図 1) 注 9)。

\section{2-2. 岐阜不燃化都市建設協議会と岐阜問屋町耐火建築促進会}

以上のように、耐火建築促進法・防災建築街区造成法を受けて、 岐皁でも不燃化を目指寸街区指定が行われ、不燃化事業が始まるが、 その事業主体を担う組織はどのように成立したのであるか。

初田の研究注 10) などにより、そうした組織については、1948(昭和 23)年に東京で都市不燃化同盟、大阪で都市不燃化促進連合会がそれ ぞれ結成されたことが明らかにされている。そして、1950 年代後半 からは都市不燃化同盟や行政からの要請を受け、全国で商工会議所 と地方行政が協力し合い不燃都市建設協議会が結成される動きがお こった。岐阜市においては岐阜商工会議所が岐阜市当局に呼びかけ、 ようやく 1959(昭和 34)年 1 月に岐阜不燃都市建設協議会が結成さ

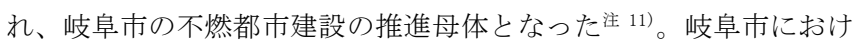
る戦災復興事業、とりわけ戦災復興都市計画事業は、他都市に比心゙ ても民間による復興意識も高く、急速に進んだものと評価されるが 注 12$)$ 、不燃化を目指寸組織成立という点においては、立ち遅れを見 せていたと判断できるだろう。

そして本稿が分析対象とする駅前の岐阜繊維問屋街については、 岐阜不燃都市建設協議会が結成されたのとほぼ同時期、1959(34)年 11 月に岐阜問屋町耐火建築促進会が結成されている。これは 


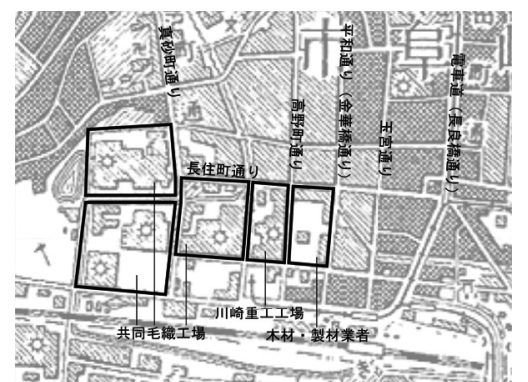

Fig. 2 Prewar land use in the Gifu railway station-front area.

図 2 戦前の岐阜駅前の土地利用状況注 16

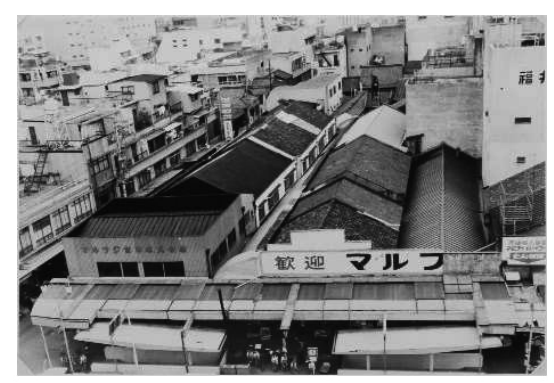

Photo 1 The Marufuji textile district. (Around 1973)

写真 1 マルフジ繊維街(1973 年頃)

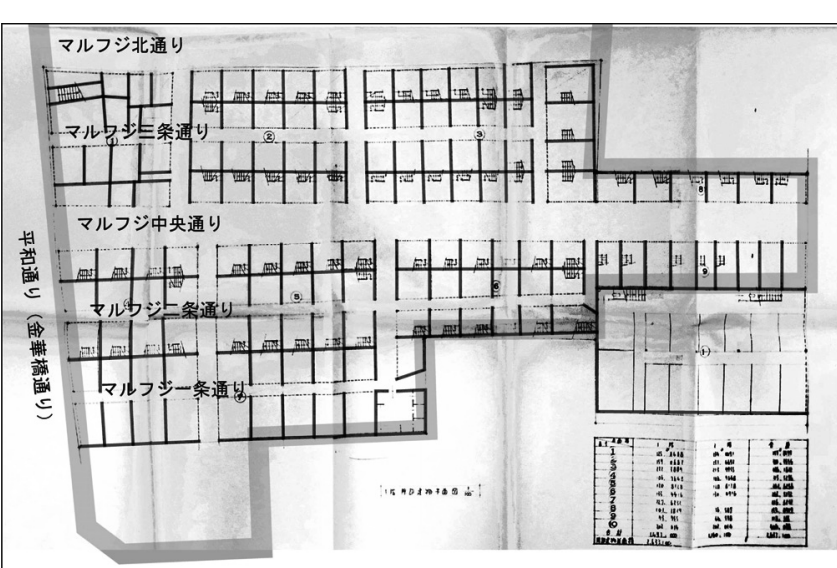

Fig. 4 The $1^{\text {st }}$ floor plan of the Marufuji textile district. (Around1973) 図 4 マルフジ繊維街一階平面図 (1973 年頃) 注 25$)$

1961(昭和 36)年から 6 力年計画で不燃化建築工事に着手すること を計画したもので、参加町内は問屋町一条通り、問屋町中央通り、 問屋町三丁目通り、問屋町一丁目、問屋町二丁目、問屋町三丁目東、 問屋町四丁目、現金問屋街、南問屋町、金町八丁目であった注 ${ }^{13)}$ 。図 1 で示すように、岐阜駅前の纎維問屋街は一帯が防火地域に指定さ れているものの、不燃化建築工事計画に参加した各問屋町では、次 項に詳述するように、すでに 1950(昭和 25)年から 1953(昭和 28)年 の間に木造店舗が密集して建設されていた主 ${ }^{15)}$ 。岐阜問屋町耐火建 築促進会は、こうした状況からの再開発を目指すものとして組織さ れたのである。

木造店舗が密集して建てられた問屋町においては、防災建築街区 造成法成立以前から不然化への気運が高まりつつあったようで、独 自の組織づくりが進められたのだが、防災建築街区造成法成立以降 はこの制度の中で繊維問屋街の不燃化が進められていくこととなっ

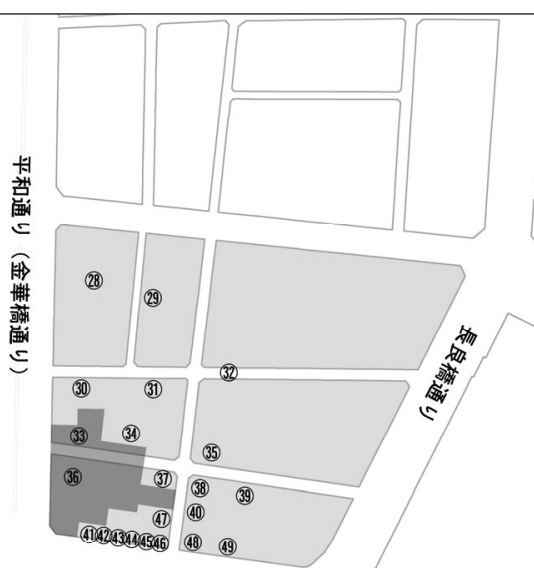

\begin{tabular}{|c|c|c|c|c|}
\hline 名称 & 場所 & 名称 & 場所 & 名称 \\
\hline 問屋町東二丁目 & (22) & 問屋町ビル & 40 & 吉野共販所 \\
\hline 中問屋町 & (28) & マルシン共販所 & (41) & 駅前共販店 \\
\hline 毛商ビル & (29) & 井銀織維街 & (42) & 福井ビル織維会舘 \\
\hline 問屋町新東一丁目 & 30 & 日/出織維 & $(43)$ & 中島ビル繊維会舘 \\
\hline 東海織維街 & (31) & 中京織維 & (44) & 丸安繊維会舘 \\
\hline 丸川繊維 & $(32$ & 住田町繊維街 & $(455)$ & 丸今繊維会舘 \\
\hline 桜繊維街 & (33) & マルフジ第一ビル & $(46)$ & 新ハルピン共販所 \\
\hline 東京繊維街 & 34 & 住田町南発展会 & (47) & 吉野緎維街 \\
\hline 丸成織維街 & (35) & 丸忠織維ビル & 48 & 駅前ビル直販所 \\
\hline 丸喜織維街 & 36 & マルフジ繊維街 & $(49)$ & 丸昭纎維共販所 \\
\hline 中央織維街 & (3) & \begin{tabular}{|l} 
サカ工織維街 \\
\end{tabular} & & \\
\hline 常盤織維街 & 38 & 有楽ビル & & \\
\hline ブラザー織維街 & & 住吉織維街 & & \\
\hline
\end{tabular}

gement of the Gifu textile wholesale districts in 1970.

図 31970 年の岐阜駅前繊維問屋街の配置注 20)

たのである。

そして実際に、岐阜問屋町耐火建築促進会の 6 力年計画に参加し た問屋町の過半数が図 1(2)、(4)内に立地し、その後順次防災建築街 区に指定されることになった。

\section{3．岐阜繊維問屋街の成立経緯}

前項では、岐阜市街地の中で䋊維問屋街が而火建築促進法・防災 建築街区造成法とそれに関連する制度の中でどのように位置付けら れることになったのかを見た。ここでは、この岐阜駅前という場所 で繊維問屋街の建設が実際にどのような経緯で実現していったかを 考察する。まず、耐火建築促進法・防災建築街区造成法などによら ない、木造店舗による問屋町の成立を見る。

岐阜駅前に䋊維問屋街が立地する場所は、戦前には大企業の工場 や木材・製材業者が立地していた。図 2 で示すように、真砂町通り と高野町通りの間の区画が工場敷地だった場所で、このうち西側が 共同毛織工場、東側が川崎重工の工場である。そして、高野町通り と平和通りの間の区画が木材・製材業者が並んだ地区である。そし て平和通りの東、金町八丁目には岐阜車輛株式会社所有の工場が立 地していた注 17)。

なお、図 2 でわかるとおり、この時点ですでに街区が造成されて いたが、それらは出村嘉史が明らかにした 1800 年代終り頃から岐 阜市と民間団体が連携するかたちで実施されていった都市基盤整備 によるものであると考えられる注 ${ }^{18)}$ 。その事業により、岐阜中心部 から鉄道駅に大道が開かれ、駅前に街区が設定された。その中に工 場と木材・製材業者が立地したのである。

そして、1945(昭和 20)年の空襲被害により岐阜市街地の $80 \%$ にあ たる約 170 万坪が焼失し注 ${ }^{19)}$ 、これら岐阜駅前の工場や木材・製材 
業者も焦土となった。その跡地に 1950(昭和 25)年ごろから纎維問 屋街が建設されるようになる。1970(昭和 45)年には、図 3 で示すよ うに 49 の問屋町が駅前一帯に成立している。このうち本稿では、 繊維問屋街建設の最初期段階である 1950(昭和 25)年から 1951(昭 和 26)年にかけて成立したマルフジ繊維街、問屋町中央通り、現金 問屋街、問屋町一条通りを取り上げる。

\section{3-1. マ、ルフジ繊維街}

最初に建設された繊維問屋街は 1950(昭和 25)年に建設が始まっ たマルフジ䋊維街である(図 3 の33、(36)。この土地は、岐阜市住吉 町料理業者の所有であったものを岐阜車輛株式会社社長・木村文蔵 氏が借りていたものであるという注 21)。この場所に注目したのが、 戦後岐阜駅前において民間団体ながら住宅開発事業を実現した北満 州からの引揚者集団だった。彼らの開発により実現した住宅街は大 ハルピン街と呼ばれ、ここにはもともと戦後直後の岐阜駅前に成立 した商店街・ハルピン街で䋊維商を営み、ハルピン街の解体により 移転してきたという住人が多くいた注 ${ }^{22)}$ 。大ハルピン街は岐阜駅か ら北西 500 メートルに位置しており、この立地が商売には不利だと 感じたハルピン街からの移転者らが、駅前に戻ろうとして建設した のがマルフジ繊維街である。

マルフジ繊維街の具体的な形成の経緯については、上記の「発展 史」に詳しい。それによれば、建設を主導したのは、ハルピン街や 大ハルピン街建設の際に民衆を斢引した高井勇を中心としたグルー プで、彼らが岐阜車輛株式会社社長の協力を得て、1950(昭和 25)年
8 月に「株式会社ハルピン街繊維斡旋所」を設立、同年 11 月には約 700 坪に及ぶマルフジ繊維街を建設した注 ${ }^{23)}$ 。建設が始まった当時 のマルフジ繊維街は、「戸板一枚の商売」が多く、「マーケット様式 の店舗で、百五十店が一軒の大商店」といった印象を与えるものだ ったようである注 24)。

では、具体的にどのような街区と建築がつくられたのであろうか。 その様子が分かるものとして、写真 1 と図 4 がある。いずれも 1973(昭和 48)年のマルフジ繊維街の取り壊しと同地の防災建築街 区造成事業に際して記録として残されたもので、岐阜県歴史資料館 所蔵の行政文書簿冊に収録されている注 26)。これらを見ると、各店 舗は壁を共有した木造長屋の形式と見られる。東西方向の通りが平 行に並んでおり、マルフジ一条通り、マルフジ二条通り、マルフジ 三条通りは各棟を貫くように建物内部に走っている通路である。マ ルフジ中央通りは、マルフジ三条通りとマルフジ二条通りを含む棟 の間の通路であるが、ここにも屋根が設置されているようである。 また、1970(昭和 45)年の問屋町連合会の会員名簿注 27) 参照すると、 これら東西の通りを挟んで向かい合った店同士が一つの町内となっ ていることが確認できた。ただし、中央通りの場合を見ると、必ず しも一つの屋根を共有している店同士が同町内ともいえない状況で あると言える。

1959(昭和 34)年には、これらの図で示されている場所の北側敷地 に「マルフジ第一ビル」が建設されていて(図 3 の(33)注28)、このビル の建設以前は同地にもこうした木造店舗が広がっていたと考えられ、

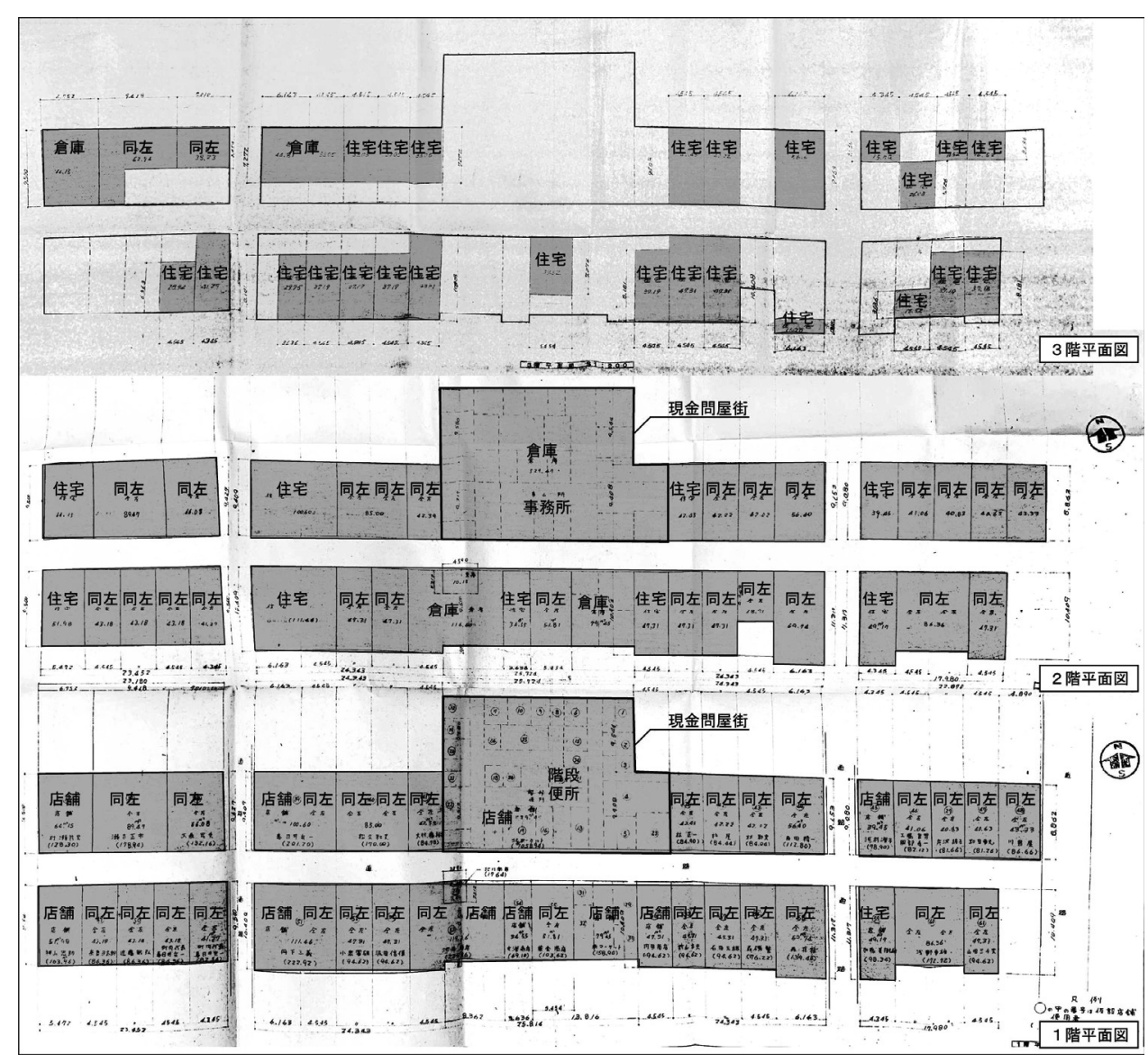

Fig. 5 The $1^{\text {st }}$ to $3^{\text {rd }}$ floor plans of Chuo-dori street and the Genkin-Tonya-gai. (Around 1966) 図 5 問屋町中央通りと現金問屋街 一階 三階平面図 (1966 年頃) 注 36$)$

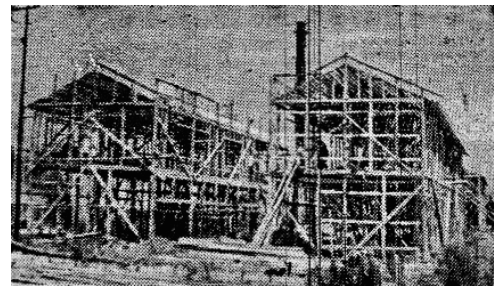

Photo 2 The Ichijo-dori street under construction.

写真 2 建設中の問屋町一条通り注 33

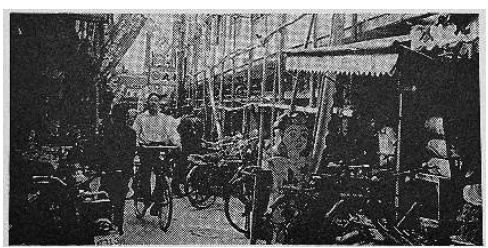

Photo 3 The Ichijo-dori street. 写真 3 問屋町一条通り注 34

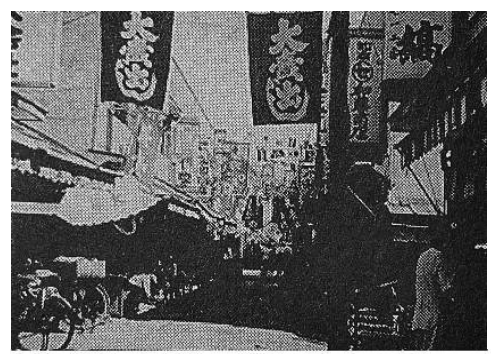

Photo 4 The Chuo-dori street.

写真 4 問屋町中央通り注 35 ) 
これも含めた一帯がマルフジ繊維街であった。

\section{3-2. 問屋町中央通り、現金問屋街、問屋町一条通り}

マルフジ繊維街に続いて次に建設が行われたのが問屋町中央通り、 現金問屋街、問屋町一条通りである(図 3 の(1)、(2)、(3))。ここは前 述の通り、戦前は共同毛織工場が立地した土地であり、戦後は工場 の撤退により跡地となっていた。そこへ、これらの問屋町が建設さ れたのだが、その経緯についても、「発展史」、「問屋町の歩み」に詳 しい。それらによると、問屋町中央通りの建設を推したのは高木保 郎注 29)らの引揚者を中心としたグループであった。そしてほぼ同時 期に、田中実司注 ${ }^{30)}$ を中心として結集した市内在住の繊維業者のグ ループが問屋町一条通りの建設を進めた。1951(昭和 26)年に問屋町 中央通りが先に買収していた共同毛織工場跡地 3,000 坪のうち、 1,000 坪を問屋町一条通りが譲り受けている。

問屋町中央通りと問屋町一条通りの両者は、計画を進めるにあた り建設委員会を設立し、会長に前岐阜市長であった松尾国松を推し た。現金問屋街も問屋町中央通りの建設の一環として高木らによっ て進められ、現金問屋街成立後は堀部勇注 ${ }^{31)}$ が発展会の会長に就い た。1951(昭和 26)年 2 月に問屋町一条通りが一部完成し開店、同年 9 月に現金問屋街、問屋町中央通りが全店完成し開店した。その建 築の様子については、問屋町中央通りは「間口二間半、奥行五間、 二階建て」、問屋町一条通りは「間口一・五間、二間、三間、三・五 間(角地)奥行五間、二階建て六棟」というものであったらしい。現金 問屋街は問屋町一条通りと問屋町中央通りにまたがるような位置に 建設された「約 400 坪のマーケット構造の商店街」で、水洗式の共 同トイレや共同炊事場、客用自転車置き場などの共同設備が備わつ ていたようである注 32 。

では、具体的にどのような街区が建設されていたのだろうか。そ れがわかる資料として、写真 $2 \sim 4$ と図 5 がある。写真 2 は岐阜新 聞(当時は岐阜タイムス)紙面で問屋街の建設が報じられた時の写真 である。写真 $3 、 4$ については、現在の繊維問屋街を束ねる「岐阜フ アッション産業連合会」によって発行された商店街誌注 37 に収録さ れたものである。そして図 5 は、問屋町中央通りと現金問屋街の取 り壊しと同地の防災建築街区造成事業に際して残された調查図で、 岐阜県歴史資料館所蔵の行政文書簿冊に収録されている注 ${ }^{38)}$ 。困 5 では問屋町中央通りと現金問屋街の 1966(昭和 41)年の様子を記録 しており、具体的な建物の用途についても確認できる。

図 5 を見ると、問屋町中央通りは、一階は店舗で二階は住居とな っているものが多く、店舗併用住宅長屋であったようである。また、 問屋町中央通りの南棟では各戸の奥行でばらつきがある箇所がある ことがわかる。そして問屋町中央通りの北棟中央に現金問屋街が配 され、ここにはより細かい店舗が内部通路を介して並んでいる。上 述の共同トイレが建物中央あたりに配置されていることも確認でき る。現金問屋街には住居としての機能はなく、問屋町中央通りとは 違った性質の街区が建設されたとみられる。

そして写真 2 は建設中の問屋町一条通りで、長屋形式で建てられ ている様子がわかる。また、当時の様子を知る問屋町の住人への聞 き取り注 ${ }^{39)}$ によると、問屋町一条通りも一階は店舗、二階は住居と いう店舗併用住宅長屋で、風呂はないものの、各戸に台所とトイレ はついていたという。

\section{4. 瀻維問屋街の不燃化}

1950(昭和 25)年から駅前で建設が始まった繊維問屋街で、初めて 鉄筋コンクリート造の建築が建てられたのは 1954(昭和 29)年の中 問屋町建設のときだった(図 3 の(15))。「発展史」によれば、この計画 は堀部勇を会長とした中問屋町繊維協同組合によって進められたと いう。現金問屋街やマルフジ繊維街などで狭い店舗にいる人たちを 糾合し、立地条件のよい土地に近代的なビルを建て集団移転させる という計画であったようだ。工事計画は第一期を 1954(昭和 29)年、 第二期を 1955(昭和 30)年として分けられた。第一期工事では 440 坪の土地に鉄筋コンクリート造三階建て、三十四社の建設を計画し、 第二期工事では 400 坪の土地に鉄筋コンクリート造の店舗十一社と 木造の店舗二十社の建設が計画された。この中問屋町の建設は、「問 屋町街づくりの総仕上げ」注 40) とも言われ、繊維問屋街の中で初め ての鉄筋コンクリート造であった事からも注目されたようである。

繊維問屋街に初めての鉄筋コンクリート造を取り入れた中問屋町 が完成してから 5 年ほどで岐阜市における都市不然化運動は活発化 してくる。2-2 で述べたように、1959(昭和 34)年に岐阜不然化都 市建設協議会が結成され、同年、繊維問屋街内部でも岐阜問屋町而 火建築促進会が結成された。そして、先述した岐阜問屋町耐火建築 促進会による不燃化建築工事の 6 力年計画のもと、その第一号とし て実現したのが問屋町一条ビルであった。

問屋町一条ビルは 1961(昭和 36)年 9 月に竣工しており、建設場 所は従来の問屋町一条通りの位置である。構造は鉄筋コンクリート 造、総建坪は 7,934 $\mathrm{m}^{2}$ 、総工費は約 2 億円であった注 41) (写真 5)。 本事業について、詳細がわかるような図面等の確認はできないが、 聞き取り注 ${ }^{43)}$ による、従来の木造店舗から再開発にあたつてはそ れぞれの店舗の地権者により希望する階高が異なったため、建物の 高さが部分により異なることとなったという。店舗ごとで平面計画 にも違いがあったが、主に一階、二階を店舗、上階を事務所や従業 員宿舎としたようである。

この他も䋊維問屋街内で鉄筋コンクリート造のビルはいくつか建 設されたことは確かだが、建設経緯や実態が明らかにできるものは 限られている。その中で、防災建築街区造成法の街区指定により不 然化が実現した問屋町中央通りの問屋町中央ビルや、マルフジ繊維 街のパレ・ワシントン・ビルについては事業計画書などが残されて いることから、次節ではそれらを基礎資料としその実態を検証する。

\section{4-1. 問屋町中央ビルの建設}

問屋町中央通りと現金問屋街にビル建設の計画が浮上するのは 1961(昭和 36)年頃のことである。2-2 で述べたように、問屋町中 央通り、現金問屋街は岐阜問屋町耐火建築促進会の不燃化建築事業 への同意を示しており、隣接する問屋町一条通りが 1961(昭和 36) 年に問屋町一条ビルを完成させたことが追い風にもなり、問屋町中 央通り、現金問屋街の一体での不燃化建築工事は 1963(昭和 38)年

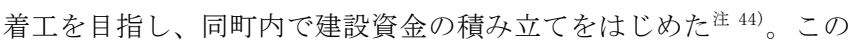
時計画された内容は、「坪あたり七〜十万円の予算で鉄筋四階建、延 建坪七、九二○平方メートルのビルを建設するもので、資金は住宅 金融公庫の融資によることとした」注 ${ }^{45)}$ とある。

なお現金問屋街の木造店舗の再開発については、岐阜日日新聞の 1961(昭和 36)年 8 月 30 日記事で上記の計画とは別な計画が記述さ れている。それは、「現金問屋街は一条ビルが完成する九月末に全店 


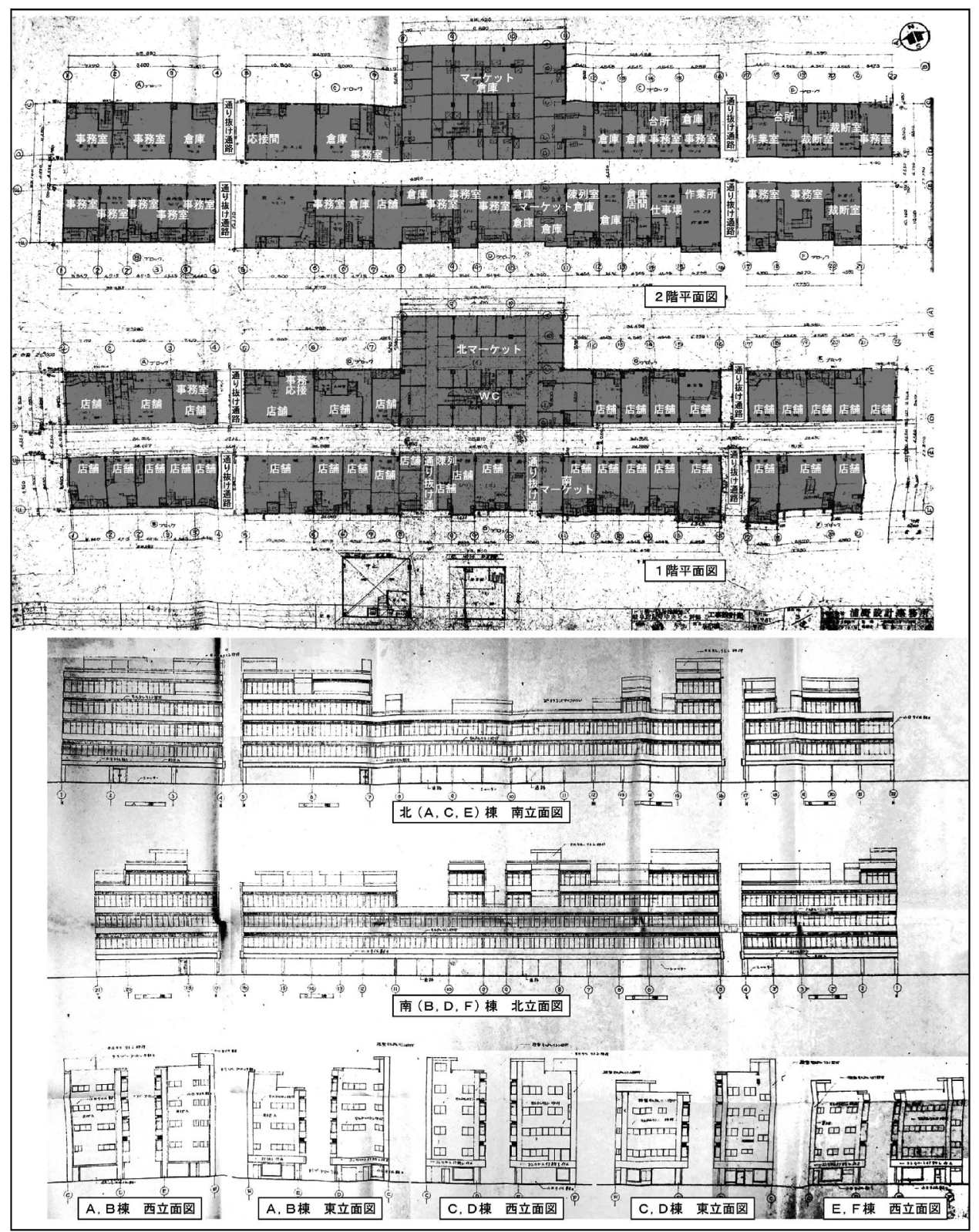

Fig. 6 Plan drawings of the Tonya-machi-Chuo Building(1967).

図 6 問屋町中央ビルの計画図面 (1967 年) 注 52

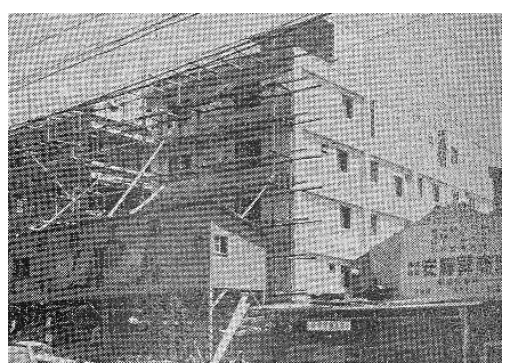

Photo 5 The Tonya-machi-Ichijo

Building under construction.

写真 5 建設中の問屋町一条ビル注 ${ }^{42}$

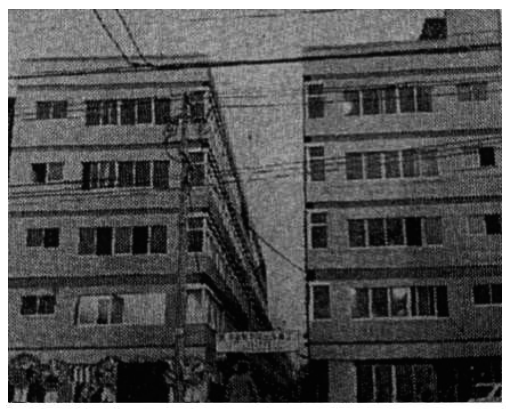

Photo 6 The Tnya-machi-Chuo Building.

写真 6 完成した問屋町中央ビル注 53)

成事業として進められることとなった。 この事業については、岐阜県歴史資料館 に所蔵された防災建築街区造成事業に 関係する行政文書からその実態を見る ことができる。

そのうち、岐阜市から建設大臣に提出 された設立認可申請書注48)からは、組合 についていくつかわかることがあり、こ れによれば、発起人は問屋町二丁目の春 日井兵一注 49)を代表とする 8 名で、組合 員は当該街区内における土地の所有者 または借地権者によって構成され、その 数は 70 名に上った。組合の設立趣旨に が一条ビルの谷間になるので店主三十七軒が相談、ビルの完成まで に間に合うよう二階鉄骨ブロック建築にかかるという意欲を見せ、 目下進行中」というものだが、この計画については実態を確認する ことはできていない。

問屋町中央通りと現金問屋街のビル建設に関しては、計画段階で は上記のような内容で、具体的な構想も練られていたと考えられる が、実際に事業が実現していくのは防災建築街区造成法施行以降で ある。岐阜市は防災建築街区造成法の施行を受け、中心市街地の柳 ケ瀬地区周辺と、岐阜駅前を中心に防災建築街区の指定を進め、問 屋町中央通りや現金問屋街を含む面積 1,4641 ha の街区を、岐阜駅 前地区問屋町第一防災街区(図 1 の (4)。以下、問屋町第一街区) とし て 1966(昭和 41)年 12 月 27 日に告示した注 ${ }^{46)}$ 。これを受け、問屋町 第一街区では事業推進母体として岐阜問屋町第一防災街区造成組合 (以下、組合)が設立された注 47 。

問屋町中央通りと現金問屋街のビル建設は問屋町第一防災街区造
は「枢要地帯に防災建築街区を造成して災害の防止を図り、併せて 土地の合理的な利用及び環境の整備改善を促進し、公共の福祉に寄 与寸る」ことが目的とある。防災建築街区造成事業は、あくまで施 行主を民間の組合とするものだが、この設立趣旨には、「公共の福祉 に寄与する」公的事業としての意義が指摘されていた点が注目され る。

次に、事業に係る費用については、岐阜市史から、総事業費は 416,087 千円で、国庫、県、市の補助金の総額は 20,520 千円であっ たことがわかっている注 50)。差額が組合の自己資金であるが、そこ には住宅金融公庫や市中銀行からの借入金も含まれていることが事 業計画書注 ${ }^{51)}$ からわかった。また、この事業計画書において「各戸 の建築物延べ面積 $(\mathrm{A}) \times$ 建築費単価 $(\mathrm{B})=$ 各戸の建築費 $(\mathrm{C}) 」$ 、「各戸の 建築費 $(\mathrm{C}) \times$ 設計料率 $(\mathrm{D})=$ 各戸の建築設計料 $(\mathrm{E}) 」$ と、各戸で必要に なる建築設計料が算出されている。そして、同計画書内の表から、 計画敷地内の各戸で個別に公庫や銀行から借入を行っていたことが 
わかった。ただし、現金問屋街の入居者らはまとまって資金計画を 立てており、公庫や銀行からの借入も共同で行っている。こうした 記録から、各戸がそれぞれの店舗の規模に応じて必要資金を工面し、 組合に積み立てるかたちをとることで、事業は実現したことがうか がえる。

では実際の建築空間の計画はどのようになっていたか。上記の事 業計画書には、図 6 のような詳細な平面図、立面図が残されており、 それらから検証する。まずは一階平面図を見ると、一連のビルは $\mathrm{A}$ から F の 6 ブロックで棟が分かれている。北棟中央の現金問屋街 は、問屋町中央通りの北に隣接する問屋町一条通りにまたがってい る。各棟を分ける隙間は南北の通路として北は問屋町一条通りへ、 南は問屋町三丁目へと慗がる。間口の幅は各戸で異なり、所によっ ては奥行も異なっている。これは建て替え前、木造店舗が建ち並ん でいた頃からの敷地割りに従って平面設計がなされたためである と考えられる。また間取りや階数も各戸で異なり、個々に合わせた 設計がなされている。立面図を見ると同じ棟の中でも階高にばらつ きがあることが一目瞭然である。こうして見ると、問屋町中央ビル の建設事業は、ビルとして一体的に建設はされたものの、その内部 は従来の店舗の敷地と建物をそのまま継承し内部に取り込んだも のと解勫できるだろう。なお、事業計画書には設計監理者は「浦野 設計事務所」とあり、名古屋市内の建築事務所であることは確認で きる注 54)。

このように内容は個別店舗のままで建物が耐火建築として一体 化した事例については、他都市にも見られた。角哲が明らかにした 秋田県大館市の事例などもその典型例である注 ${ }^{55)}$ ここうした場合、 不規則な空間配置が必要になり、平面計画上において、一体的な建 築としての合理性が損なわれることになる。秋田県大館市における 防火建築帯の設計を行った池辺陽は、雑誌『建築界』で商店建築を 共同化する事業について、「一般にこれらの建築を全くの自己建築 と考えてつくる建主や、又その立場で取扱う官庁等がまだまだ多い ことは残念なことであって、共同建築の建築と都市計画との結合を もっともっと積極的に推し進めればならない」と指摘している注 56)。 一方で、池辺は同雑誌において、「鉄筋コンクリートを主構造とし、 壁をブロックなどの外し得るものとして計画された共同建築は、… 構造の持つ長い寿命を有効に生かすことができる。この考え方は鉄 筋コンクリートによってつくられる構造物を、従来の意味での建築 という概念でつくらず、立体的な敷地造成という概念でとらえ、そ の内部に個々の商店という建築をはめこむものと云ってよいだろ う」注 57) とも指摘している。これに対し、完成した問屋町中央ビル について報じた 1967(昭和 42)年 11 月 12 日の岐阜日日新聞記事に は、「ビルは将来の駐車場難を見込んで、一階は壁をはずすと全面駐 車場へ一変すると同時に、二階に通路が設けられるように設計され ている」との記述がある。問屋町中央ビルの将来の改修を見越した 計画は、池辺が指摘したこうした将来計画を含んだ計画性が見られ るものとも考えられ、注目すべき点と言える。

\section{4-2. パレ・ワシントン・ビルの建設}

マルフジ繊維街の不燃化事業は、マルフジ北通り(図 4)以北と以南 で、大きく二地区に分かれている。マルフジ北通り以北の方が先に、 不燃化事業としてマルフジ第一ビルが完成している(図 3 の(33)。「発 展史」によると、マルフジ第一ビル第一期工事が 1959(昭和 34)年 6
月に完了しており、総建坪 $265 \mathrm{~m}^{2} 、$ 二階建てというものだった。 1963(昭和 38)年 3 月には拡大工事が完了し、1966(昭和 41)年 8 月 にはビルの一部を鉄筋コンクリート造の防火建築に改築している。

建設事業を進めた代表は木村文蔵で、マルフジ繊維街の建設敷地 となった工場跡地の岐阜車輛株式会社社長で、マルフジ繊維街建設 時に設立された「株式会社ハルピン街繊維斡旋所」の社長となった 人物である。

このマルフジ第一ビルについての一連の事業は図面等の所在が確 認できず、事業の経緯や詳細について把握することが困難だが、岐 阜日日新聞の 1967 (昭和 42)年 8 月 22 日記事には、「一昨年の火事 にこりたマルフジ䋊維街は鉄筋コンクリートづくりに改築した」と ある。1965(昭和 40)年 11 月 14 日にマルフジ繊維街三丁目あたりか ら出火し、34 店が全半焼したが、このことが 1966(昭和 41)年の鉄 筋コンクリート造化のきっかけになっていると考えられる。

マルフジ北通りの以南については、0.266ha が 1963(昭和 38)年 2 月 1 日に岐阜駅前第一防災街区(図 1 の(2)。以下、岐阜駅前第一街 区)に指定されている。この街区は問屋町第一街区(図 1 の(4))よりも 先に街区指定を受けているが、街区内のマルフジ繊維街でビル化が 完了寸るのは 1974(昭和 49)年と、街区指定から 10 年ほどの間があ る。この間、同街区内で防災建築街区造成法適用の建築としては福 井ビル(図 3 の(41)から (46)までの全てを含むビル)が 1963(昭和 38)年に 竣工するなど、街区の南辺の建物については既に耐火建築化が完了 している。

ここまでマルフジ繊維街が而火建築化に着手できなかったのには いくつか理由があった。「発展史」によると、「株式会社ハルピン街 繊維斡旋所」はこの時には「まるふじ商事株式会社」(以下、まるふ

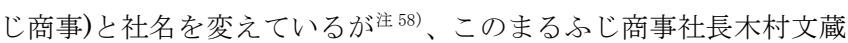
氏の言う事には、「社として訴訟問題などがあって、43 年 11 月問題 が解決するまで全然手がつけられなかった」注 59) という。そして問 題を解決後、1971(昭和 46)年にマルフジ繊維街の場所に高層ビルを 建設する計画を具体的に発表した。しかしここでも問題が発生した。 この計画で木村社長は 12 階建てビルを建設し、大型スーパーを誘 致する計画を発表したことで、マルフジ繊維街の住民に反発を受け たというものである。マルフジ繊維街の商店を束ねるマルフジ繊維 連合会は反対決議文を出し、この事業に強く抗議した。その結果、 この計画も流れることとなり、マルフジ繊維街の耐火建築化は先延 ばしになったの である。

こうした経緯 を経て、1973(昭 和 48)年 4 月によ うく防災建築 街区造成事業と してマルフジ繊 維街の耐火建築 化、パレ・ワシン トン・ビルの建設 が始まった。防災 建築街区造成法 は 1969(昭和 44)

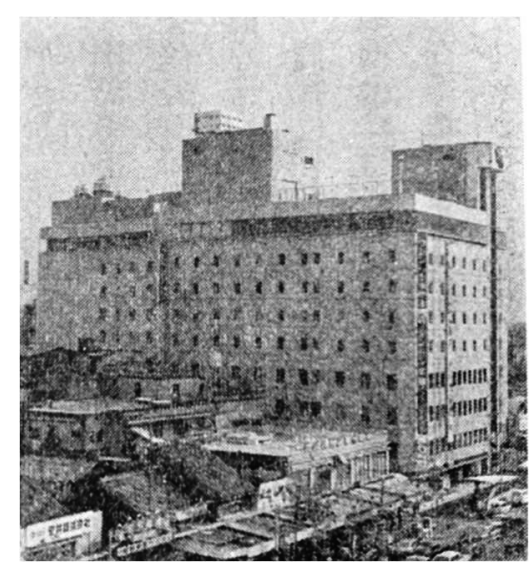

Photo 7 The Palais Washington Building.

写真 7 完成したパレ・ワシントン・ビル注 62) 


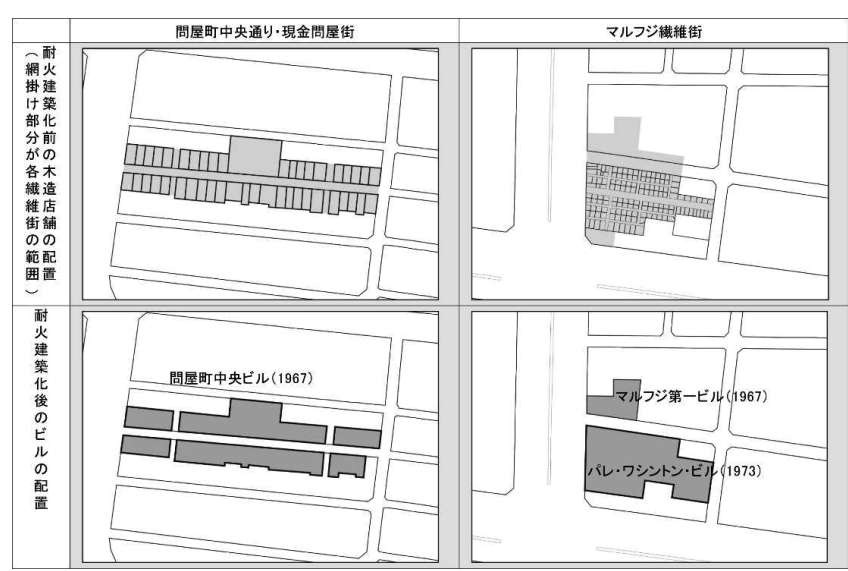

Fig. 7 The fireproof buildings constructed integrally. 図 7 不燃化と店舗の共同化

年に廃止され、その後 1976(昭和 51)年までの間、経過措置期間がと られた。パレ・ワシントン・ビルの建設事業は経過措置期間に進行 したと考えられる。この事業について、岐阜県歴史資料館所蔵の防 災建築街区造成事業に関係する行政文書注 60$)$ からは、事業の内容が 二転三転した実態も垣間見ることができる。

決定した事業計画について、その計画書をもとに追ってみる。建 設地となったのはマルフジ北通り以南である。ビルは鉄筋コンクリ ート造九階建てで、建築面積約 $1,651 \mathrm{~m}^{2}$ 、延べ床面積 $17,185 \mathrm{~m}^{2}$ と 計画されていた。設計者は「駒井伊藤建築設計事務所」とあり、名 古屋市内の建築事務所であるということが確認できる。

本事業の建設推進母体となったのは 1968(昭和 43)年に結成され た岐阜駅前繊維防災建築街区造成組合で、組合員は木村文蔵氏を代 表に、ほか 4 名であった。組合員が 70 名以上で構成されていた問 屋町第一防災街区造成組合の場合とは大きく異なる。

また、岐阜市史によれば、総事業費は 29 億円、このうち国庫補助 が約 1 億 5,149 万、県補助が約 7,874 万、市補助が 7,874 万であっ たとされているが注 61)、事業計画書から、この他、市中銀行からの 借入金も利用したものと確認できる。

ビルの階層別用途については、「発展史」によれば、地下二階は機 械室、地下一階は食料品店街、地上一階から二階が繊維卸街、三階 から四階が事務所、五階から八階がビジネスホテル、九階がレスト ランという内容であった。そして、元々この場所に店を構えていた マルフジ繊維街と吉野繊維街(図 3 の承)の約一五○店が一、二階に 入居することになったという。また展示会場、会議室、貸事務所、 サウナ、スチームバスなどの施設も併設したとの記述もある。

パレ・ワシントン・ビルの事業では、問屋町中央通りビルと比較 してもかなり大規模なビル建設を行っており、また各階層で用途が 分かれているなど、個別の店舗が元の敷地割のまま共同建築化した 事例とは違った様相を呈している(写真 7)。この事業は単に繊維問屋 街の不燃化に留まっておらず、「発展史」でも、この事業について、 「岐阜駅前の再開発の一環として、新しいファッション・ビジネス の集団化」を目指した試みであったとしている。

\section{5. おわりに}

以上、戦後の岐阜駅前に形成された繊維問屋街の形成と不燃化事 業に伴うその後の展開について検証した。ここで了解されたことは、
1950(昭和 25)年に建設が始まったマルフジ繊維街から、1973(昭和 48)年のパレ・ワシントン・ビルの建設に至るまで、23 年という間 に、きわめて多様な形での街区建設が現れたという事実である。

マルフジ䋊維街から問屋町中央通りおよび問屋町一条通りの街区 建設では、その前史とも言える大八ルピン街から続けられた、木造 長屋形式の建築が一体的に作られた。大ハルピン街建設においては、 強力なリーダーシップを持つ有力者の尽力により事業が進んだが、 マルフジ繊維街、問屋町中央通り、問屋町一条通りの街区建設では、 そうしたリーダーに代わり、商店主たちの自主的・自律的な活動に より、街区を建設していった状況がうかがえた。

その後、全国におよんだ不燃化運動により耐火建築促進法が制定 されると、岐阜繊維問屋街でも、岐阜問屋町耐火建築促進会が結成 され、鉄筋コンクリート造による街区のビル化が進んでいった。も ちろん、その事業化は行政による支援・指導によるものだが、事業 主体は繊維街などによって組織される組合であった。それでも、中 問屋町の街区建設では、既存の問屋街などの商店を糾合し、立地条 件のよい土地に集団移転させるという目的が設定されていたし、問 屋町中央ビルでは、単なる不燃化ではなく土地と環境の整備事業で あるという目的が設定されていた。つまり、事業には個別の商店主 の利益だけでなく、共同化することによって獲得できるであろう公 的な利益が見据えられていたのである。

しかし一方で、他の都市での耐火建築促進法・防災建築街区造成 法下の不燃化事業にも見られたように、その共同化された建築では、 各々の商店の敷地や形状がそのまま建物内に踏襲され、建物として の統一感を欠く設計が行われたことがわかった。そこには、不燃化 事業が共同化により初めて実現できる、つまり共同化事業であるこ とが前提になりながら、個々の商店の地権を優先しなければならな かったという、事業そのものの性格、あるいは限界が表れていたと 言えるだろう。

ただし、パレ・ワシントン・ビルの建設に至ると、ビル建設自体 が、新しいビジネスの展開として捉えられたものになっていく。そ こでは、既存の商店の共同化は事業の主目的とならず、スーパーや ホテルなどの外部の事業者を受入れるという、現在の商業ビルのビ ジネスと同様の事業形式が現れた、と解釈することができるだろう。 本稿では、駅前という空間にもかかわらず、繊維問屋街という一 つの業態に特化して成立した街区の建設に着目した。そこでは、戦 後初期の「闇市」にも通じる、自律的な商店街（ハルピン街）を引 き受ける形で、商店主たちの事業共同化が進み、さらに耐火建築促 進法という制度的枠組みの中でのビル化事業が進むという、戦後の 20 年あまりの間に起こった一連の経緯が、それぞれの過程を引き継 ぐようにして連続的に行われていった、という実態が明らかになっ た。これは、現在も引き継がれている繊維問屋街という、一つの業 態の共同化という事態でこそ見られたものではなかったかと考えら れる。

もちろん、繊維業だけではないだろう。戦後の日本の経済発展を 支えた各種の産業は、さまざまな形で多様な街区を形成していった はずである。今後は、産業の発展との関わりという観点から、さら に多様なわが国地方都市の商業街区の形成を検証していくことを課 題としたい。 
参考文献

1) Gifu City, Gifu City history present edition, 1981. 11 (in Japanese) 岐阜市：岐阜市史通史編現代, 1981. 11

2) Gifu City, Gifu City history present edition, 1980. 3 (in Japanese) 岐阜市：岐阜市史史料編現代, 1980. 3

3) Gifukiseifukusangyourengoukai: Gifukiseifukusangyouhattennshi, Tokaisennikeizaishinnbunsha, 1975 (in Japanese) 岐阜既製服産業連合会：岐阜既製服産業発展史，東海繊維経済新聞社， 1975

4) Gifusennitonnyamachirenngoukai: Kaiinnmeibo, 1970 (in Japanese) 岐阜繊維問屋町連合会: 会員名簿, 1970

5) Yoshiyuki MIYOSHI: Gifusennitonnyamachirenngoukaikessei20syu unenn Tonnyamachinoayumi Gifusannchinohitobito, Tokaisennikeizai shinnbunnsha, 1971. 12 (in Japanese)

三次義之: 岐阜繊維問屋町連合会結成 20 周年 問屋町の歩み 岐阜産地 の人々，東海繊維経済新聞社, 1971. 12

注

注 1）代表的な研究として、初田香成：都市の戦後 雑踏のなかの都市計画と 建築, 東京大学出版会, 2011、石槫督和：戦後東京と闇市 新宿・池袋・ 渋谷の形成過程と都市組織，鹿島出版会, 2016、村上しほり：神戸 闇 市からの復興一占領下にせめぎあう都市空間, 慶応義塾大学出版会, 2018 などがある。

注2）初田香成：都市の戦後 杂隹踏のなかの都市計画と建築，東京大学出版会, 2011、角哲・越澤明: 秋田県大館市の防火建築帯を中心とした大火復 興による都市形成, 日本建築学会計画系論文集第 80 巻, 第 713 号, pp.1707-1715, 2015.7、中島直人：藤沢駅前南部第一防災建築街区造成 の都市計画史的意義に関する考察，日本建築学会計画系論文集第 78 巻， 第 688 号, pp.1301-1310, 2013.6、など。

注 3）荒木菜見子・中川理：戦後復興期における岐阜駅前商業地区の形成過程 に関する研究一ハルピン街の設立と展開を中心に一, 日本建築学会大 会学術講演梗概集, pp.437-438, 2016.8。

注 4）参考文献 3)。

注 5）参考文献 5)

注 6）前掲、荒木菜見子・中川理：戦後復興期における岐阜駅前商業地区の形 成過程に関する研究一ハルピン街の設立と展開を中心に一, 日本建築 学会大会学術講演梗概集, pp.437-438, 2016.8。

注 7) 岐阜市役所都市計画課：戦災復興誌岐阜市, 1958 p.12。

注 8）防災建築街区造成法の概要については、社団法人全国市街地再開発協 会: 日本の都市再開発史，1991 から。

注 9）参考文献 1） p.152。

注 10）初田香成：沼津本通防火建築帯について一都市不燃化運動の地方都市 における事例研究一, 日本建築学会大会学術講演梗概集(関東), pp.333-334, 2006.9、初田香成, 1950 年代の都市不燃化運動の全国的 展開に関する基礎的整理, 日本建築学会大会学術講演梗概集(九州), pp.415-416, 2007.8、など。

注 11）参考文献 3） p.162。

注 12）浅野純一郎：地方都市の戦災復興都市計画における当初計画理念の成 立と戦前・戦中都市計画との関係性について一熊本, 高知, 岡山, 岐阜 を対象として一, 日本建築学会計画系論文集第 77 巻, 第 671 号, pp.27-36, 2012.1 から。

注 13）参考文献 3） p.160。

注 14）岐阜県歴史資料館所蔵、行政文書簿冊『防災街区県補助申請書(問屋 町)基本計画作成費 建築住宅課 昭和 41 年』、『防災街区 2 冊の 1 建築住宅課 昭和 44 年度』に収録の地図と、参考文献 1） p.152 から 筆者作成。原資料の岐阜都市計画用途地域図は 1966 年のもの。

注 15）参考文献 3） pp.31-39。

注 16) 国土地理院地図 1932(昭和 7)年をもとに筆者作成

注 17）富樫幸一・合田昭二・白樫久・山崎仁朗：人口減少時代の地方都市再 生一岐阜市に見るサスティナブルなまちづくり一，古今書院，2007。

注 18）出村嘉史「近代岐阜の「市区改正」とその運営」（日本建築学会計画系 論文集第 77 巻, 第 677 号, 2012.7)pp.1643-1652、出村嘉史「岐阜の 初期都市計画における土地区画整理事業」(日本建築学会計画系論文集 第 78 巻, 第 694 号, 2013.12)pp.2529-2536。

注 19）参考文献 1） p.130。

注 20）参考文献 4)をもとに筆者作成。
注 21）東海夕刊 1950(昭和 25)年 11 月 24 日記事から。

注 22）前掲、荒木菜見子・中川理：戦後復興期における岐阜駅前商業地区の 形成過程に関する研究一ハルピン街の設立と展開を中心に一, 日本建 築学会大会学術講演梗概集, pp.437-438, 2016.8。

注 23）参考文献 3） p.27。

注 24）カギ括弧は参考文献 3） p.27、p.72 から引用。

注 25）前掲、岐皁県歴史資料館所蔵、行政文書簿冊『防災街区額の確定 建 築課 昭和 48 年度』に収録の図面に、情報を加筆し筆者作成。

注 26）岐阜県歴史資料館所蔵、行政文書簿冊『防災街区額の確定 建築課 昭 和 48 年度』に収録。

注 27）参考文献 4)

注 28）参考文献 3） p.157、参考文献 4） p.108、国土地理院の空中写真(1961 年)から。

注 29）高木保郎は岐阜県生まれで戦中は南満州鉄道に在籍し、1946(昭和 21) 年に岐阜に引揚げ後、繊維問屋街の建設時に活躍した人物である。問 屋町中央通りの建設につづき、問屋町三丁目本通りの建設も推し進め た。経歴については参考文献 5)から。

注 30）田中実司は株式会社岐阜䋊維取引所を経営していた人物で、1951(昭 和 26)年 12 月に結成された岐阜繊維問屋町連合会の初代会長に就いて いる。経歴については参考文献 3)、参考文献 5)から。

注 31）堀部勇は 1948(昭和 23)年に岐阜に引揚げてきてから既製服問屋を始 めた。岐阜繊維問屋町連合会設立時は総務として活躍、1954(昭和 29) 年の鉄筋コンクリート造ビルによる中問屋町建設の際には自ら組合長 となり事業を军引した。経歴については参考文献 5)、東海夕刊 1956(昭 和) 31 年 9 月 10 日記事から。

注 32）力ギ括弧は参考文献 3） p.31、p.32 から引用。

注 33) 東海夕刊 1950 (昭和 25)年 8 月 13 日に掲載。

注 34） 前掲、社団法人岐阜ファッション産業連合会：ファッションのまち岐 阜一岐阜せんい問屋街のあゆみと現在一, 1998 p.4 に掲載。

注 35）前掲、社団法人岐阜ファッション産業連合会：ファッションのまち岐 阜一岐阜せんい問屋街のあゆみと現在一, 1998 p.4 に掲載。

注 36) 前掲、岐阜県歴史資料館所蔵、行政文書簿冊『防災街区造成事業(組合 設立認可申請 問屋町第一) 建築住宅課 昭和 41 年』に収録の図面 に、情報を加筆し筆者作成。

注 37）社団法人岐阜ファッション産業連合会：ファッションのまち岐阜一岐 阜せんい問屋街のあゆみと現在一, 1998。

注 38) 岐阜県歴史資料館所蔵、行政文書簿冊『防災街区造成事業(組合設立認 可申請 問屋町第一) 建築住宅課 昭和 41 年』に収録。

注 39）問屋町一条通り、問屋町中央通りにそれぞれ店を構える店主 2 名を対 象に、2020 年 6 月 12 日、6 月 17 日に聞き取り調査を実施した。

注 40） カギ括弧は参考文献 3） p.59 から引用。

注 41）参考文献 3） 194、毎日新聞 1961(昭和 36)年 8 月 26 日記事から。

注 42) 毎日新聞 1961(昭和 36)年 8 月 26 日記事に掲載。

注 43) 注 38)前掲の聞き取り調査。

注 44）参考文献 3） p.194。

注 45）力ギ括弧は参考文献 3） p.194 から引用。

注 46）参考文献 1） p.152。

注 47）参考文献 3） p.321。

注 48）岐阜県歴史資料館所蔵、行政文書簿冊『防災街区造成事業(組合設立認 可申請 問屋町第一) 建築住宅課 昭和 41 年』に収録。

注 49) 春日井兵一は 1933(昭和 8)年、岐阜県立農林学校を卒業の後、南満州 に渡り、南満州鉄道会社に入社、1946(昭和 21 ) 年に岐阜に引揚げ後は、 1950(昭和 25 )年に問屋町二丁目に繊維問屋を開店した人物である。略 歴については岐阜県歴史資料館所蔵、行政文書簿冊『防災街区造成事 業(組合設立認可申請 問屋町第一) 建築住宅課 昭和 41 年』に収録。

注 50）参考文献 2） p.79。

注 51）前掲、岐阜県歴史資料館所蔵、行政文書簿冊『防災街区県補助申請書 (問屋町)基本計画作成費 建築住宅課 昭和 41 年』に収録。

注 52）前掲、岐阜県歴史資料館所蔵、行政文書簿冊『防災街区県補助申請書 (問屋町)基本計画作成費 建築住宅課 昭和 41 年』に収録の図面に、 情報を加筆し筆者作成。

注 53) 岐阜日日新聞 1967(昭和 42)年 11 月 12 日に掲載。

注 54）「浦野設計事務所」は 1950 (昭和 25) 年に「浦野三男建築事務所」と して名古屋市で創設されていることが確認できる。

注 55）前掲、角哲：秋田県大館市の防火建築帯を中心とした大火復興による 都市形成，日本建築学会計画系論文集第 80 巻，第 713 号, pp.1707- 
1715, 2015.7 から。

注 56）池辺陽：商店建築の共同化について, 建築界第 4 巻, 第 5 号, pp.19-23, 1955. 5。力ギ括弧は p.23 から引用。

注 57） カギ括弧は前掲、池辺陽：商店建築の共同化について, 建築界第 4 巻, 第 5 号, pp.19-23, 1955.5 p.19 から引用。

注 58）参考文献 3)によれば、「株式会社ハルピン街繊維斡旋所」は「富士繊 維販売株式会社」、「まるふじ商事株式会社」と社名変更している。

注 59） カギ括弧は参考文献 3） p.417 から引用。

注 60）岐阜県歴史資料館所蔵、行政文書簿冊『防災街区造成事業計画 3 冊 の 1 建築課 昭和 47 年度』に収録。

注 61）参考文献 2） p.78。

注 62）参考文献 3） p.479 に掲載。 


\title{
STUDY ON THE CITY BLOCK CONSTRUCTION OF THE TEXTILE WHOLESALE DISTRICTS
} IN THE GIFU RAILWAY STATION-FRONT AREA.

\author{
Namiko ARAKI*1 and Osamu NAKAGAWA*2 \\ ${ }^{* 1}$ Grad. Student, Dept. of Architecture, Kyoto Institute of Technology, M.Eng. \\ ${ }^{* 2}$ Prof., Faculty of Design and Architecture, Kyoto Institute of Technology, Dr.Eng.
}

This study targets the textile wholesale districts in front of JR Gifu railway station, and it aims to clarify the forming process and the transformation of the districts from the post-war period to the adaptation of the disaster prevention zone and its aftermath.

The textile wholesale districts were established in the post-war period. The land lot of the district was developed in the late 1800s. Factories and lumber dealers were located there, but they were all burnt down by the air raid bomb in 1945. Afterwards the textile dealers came to settle to form the wholesale districts.

The first textile district there was the Marufuji textile district, which was constructed in 1950 . This site was located northeast of Gifu railway station in nagaya or wooden row house style, with a number of buildings standing parallel to each other in the east-west direction and roofed pathways running in-between. Subsequently the Chuo-dori street and the Ichijo-dori street were constructed from 1951 at the former factory site northwest of Gifu station. Either in nagaya style, shop space was on the ground floor and residence on the upper floor. As part of the construction of the Chuo-dori street, the Genkin-tonya-gai or cash-basis wholesale street was equipped in the collective-shop style, along with common facilities such as toilets or kitchen.

The textile wholesale districts in front of Gifu railway station were formed in the course of the post-war rehabilitation period at the midst of densely packed wooden structures. Afterwards in 1950s, the nation-wide spread of the city fireproof movements affected the Gifu wholesale district, which was then expected to be redeveloped.

With the support of the government, Association for the Promotion of Fireproof Building in Gifu Tonya-machi was formed in 1959, and the Ichijo-dori street was redeveloped into a fireproof building in 1961. Consequently in 1967, the Chuo-dori street and the Genkin-tonya-gai were also redeveloped into fireproof style, which was conducted as a project under the Disaster Prevention Building Block Development Act. All of the buildings there were integrally reconstructed in a single building form, while the premises of the shops were inherited and incorporated into the new building.

On the other hand, the Palais Washington Building, which had nine stories above ground and two stories underground, was constructed in 1973 as part of a Disaster Prevention Building Block Development project in the area where the Marufuji textile district was located. While the first and the second floors of the building were allocated to textile wholesale area, including the shops from the Marufuji textile district, the upper floors accommodated tenement businesses of hotels or restaurants, which was almost equivalent to the present business form of commercial buildings. In the post-war period, independent efforts of influential persons founded nagaya style wooden market in the Gifu station-front area. Autonomous cooperation of shop owners formed the textile wholesale district in the next phase. On the other hand, wooden shops districts in front of Gifu railway station were altered into fireproof buildings in the course of the nationwide fireproof movement. Regarding the cases in the timeline of twenty years, this paper detects the transitions of the business forms or purposes in the cooperation of the districts. 